\title{
Possible Applications of the Theory of Transaction Costs in Corporate Management
}

\author{
Justyna Suska*
}

\begin{abstract}
Objective - transaction costs theory is one of three new - neoclassical - concepts of an enterprise, constituting the opposition to classical theories perceiving a company as a "black box", that is a closed body (black box), the aim of the company is to effectively transform inputs into outputs. and the effectiveness analysis is performed through the prism of production costs. Market mechanisms regulate the functioning of the market, since companies operate on the market perceived as a sphere of confrontation between supply and demand (equilibrium of price). The neo-classical approach did not take into account the pressure of different institutions regulating the business activity environment. Neo-institutional theories focus on perceiving a company more broadly than as a "black box", and through the prism of the production function. The aim of the article is to present scientific studies regarding the possibility of using the theory of transaction costs in enterprise management.

Methodology of research - For the purposes of this study the following test methods were used: a critical analysis of professional literature, a diagnostic survey (scenario) and a comparative studies method. Moreover, methods such as synthesis, deduction and induction were used.

Result - The studies demonstrated that the comparison of transaction costs should decide on the coordination of activities by a company and not by the market - if transaction costs are lower inside a company, it is profitable to organize the production within this company, if they are higher on the market than in the company - production of goods by the company will be unprofitable. In this context, it is important to take into account the internal solutions in companies - assuming that most of the factors of production are actually used by companies and the use of these assets is subject to the decisions of companies, and not directly to the activities of market forces. The functioning of the market depends, to a large extent, not on market forces, but on the manner in which companies operate.

Originality/value - The conducted analysis provides the foundation for a discussion on the implementation of the transaction costs theory by, among others, the creation of purchasing groups in order to improve the negotiating position with partners (reducing the costs of searching for information) or the use of a third-party's employees (temporary work - reducing the cost of production preparation).
\end{abstract}

Keywords: cost management, economics of transaction costs, information asymmetric, institutional economy, contractual theory of an enterprise

\section{Introduction}

Transaction cost theory is one of three new - neoclassical - concepts of an enterprise, constituting opposition to the theory of classical theories perceiving an enterprise as a "black box", that is as a closed body (black box), the aim of which is to effectively transform

\footnotetext{
* mgr Justyna Suska, studentka studiów doktoranckich, Uniwersytet Ekonomiczny w Katowicach, Wydział Zarządzania/Barry Callebaut Zundert, Holandia, e-mail: justina_suski@interia.eu.
} 
inputs into outputs and an efficiency analysis is conducted through the prism of production costs. Market mechanisms regulate the functioning of the market, since enterprises operate on the market which is treated as a sphere of confrontation between supply and demand (equilibrium of price). The neoclassical approach, on the other hand, has not taken into account the pressure of different institutions regulating the conditions of conducting business activity.

In the case of the neo-institutional theories the focal point is the perception of the enterprise more broadly than as a "black box" and through the prism of the production function. Precursor of one of the non-institutional theories, the aforementioned theory of transaction costs, Ronald Coase, said that the neoclassical approach did not take into account transaction costs. These are costs directly related to the presence of the enterprise on the market, primarily the costs of searching for information on potential customers and partners of goods manufactured by the enterprise, the cost of preparing contracts and supplies, and the cost of enforcing contracts. These are the costs of maintaining the market system that is transaction costs incurred by the market, rather than transaction costs incurred by the enterprise. In the theory of transaction costs the enterprise is treated as a management structure, not as a production function. The comparison of transaction costs should decide on the coordination of activities by the company and not by the market - if transaction costs are lower inside the company, it is profitable to organize the production within this company, if they are higher on the market than in the company - the production of goods by the company will be unprofitable. In this context it is important to take into account the internal solutions in companies - assuming that most of the factors of production are actually used by enterprises, subject to the decisions of companies and not directly due to the activities of market forces. The functioning of the market depends, to a large extent, not on market forces, but on the manner in which the enterprises operate. Examples of the implementation of the transaction costs theory include the creation of the buying groups, in order to improve the negotiating position with partners (reducing the costs of searching for information) or the use of third-party's employees (temporary work - reducing the cost of production preparation).

The theory of transaction costs was rediscovered in the 1990s due to O. Williamson who studied the conditions for achieving the harmonious cooperation of enterprises and eliminating the conflicts related to this issue. According to this scholar, agreement could be achieved through properly functioning institutions and a microeconomic analysis of the enterprise and its management manner aimed at minimizing the transaction costs. Transaction costs are assessed according to the criteria of their optimization. New institutional economics refers to the theory of enterprise by Coase. It focuses on institutions at a microeconomic level, in other words contracts perceived as limited cooperation institutions (Zbroińska 2013, p. 164).

Apart from Coase, K. Arrow, who was the first to use the term "transaction costs" made a contribution to the theory of transaction costs as well as H. Simon, who developed the behavioural concept of a company. Simon also introduced the concept of the limited liability 
of business entities which is important for the transaction costs theory. A significant figure in the development of this theory was O. Williamson as well. His economics of transaction costs constitutes an institutional approach to the study of an organization, in which the main unit of analysis is the transaction (Lichtarski 2007, p. 34). Commons made a particular contribution to the development of the institutional trend, which focused on the impact that institutions had on the decisions and functioning of enterprises. He was also one of the first individuals who moved the center of gravity as regards to the analysis from the factors of production to transactions.

Currently, the transaction cost theory is incorporated into, in addition to the agency theory and property rights theory, the canon of the new institutional economics. The genesis of its creation, however, suggests a close relationship with both the neoclassical theory of the enterprise and works of Neo-Keynesians from the 1950s and 1960s. Its unquestionable advantage is its multi-dimensional character, manifesting itself in being able to be applied in many areas of economics and management. This concept raises issues of property rights, the forms of organizing transactions and limits on the operation of companies, but also mathematical and statistical models of growth present in the economy (Klaes 2000, p. 192).

The transaction cost theory emerged on the basis of criticism of the neoclassical theory of the company, which was accused of not taking into account the impact of many factors (the issue of accepted assumptions). According to the neoclassical theory, an enterprise operates on the market perceived as a place of confrontation between supply and demand, which leads to the determination of prices to ensure market balance. Such an approach ignores the impacts of various kinds of institutions thus creating an environment for conducting business activity and, in particular, ignores completely the transaction costs (costs of searching and collecting information on finding potential partners, the cost of preparing the contract, the cost of enforcing the provisions of the contracts), which are closely related to the presence of the company on the market (Wrońska 2012, p. 139).

In the transaction costs theory, which is one of the trends of institutional economics, incorporated in the mainstream of the neoclassical approach, institutions, contracts and transaction costs are gaining fundamental importance. The research focuses on enterprises and thus, on the micro-economic environment and manner of management. The neo-institutional theory is based on the notion of transaction (contract) as the analysis unit. Such an understanding is associated with Williamson's hypothesis according to which any problem can be interpreted as a contract. In turn, its conclusion and implementation require incurring transaction costs. These costs become an effective measure of efficiency regarding the whole institution, and their use is far beyond the relations of exchanging goods in a given market. Transaction costs are therefore present in every sphere of human activity, not only in market conditions. This is due to the fact that man exists in a world of contracts of varying intensity concerning uncertainty (Zbroińska 2013, p. 165). 


\section{The notion and significance of institution for the transaction costs theory}

The concept of institution, in the theory of transaction costs, means that the rules of the game and limitations created by people, shaping the interaction and forming the structure of incentives on interacting participants of the exchange, make the world more predictable (Klimczak 2005, p. 16). The organization is, therefore, an entity equipped with resources, pursuing goals with the help of these institutions. Simply put, the organization is a player and the institutions are the rules of the game (Ząbowicz 2003, pp. 795-823). The largest organization with the resources is the state which creates the institutional environment, and the legal system is its element.

As regards to the theory of transaction costs institutions can be divided into formal, understood as internal standards of organizations and informal, which are perceived as a moral standards not enforced as the law. Informal institutions include, therefore, customary norms, and certain patterns of conduct that shape human behaviour. Changes taking place in these institutions require time, because items such as habits, procedures, ethics and honesty undergo modification. Characteristics of the institution should be treated as personality traits, which also include ambition, diligence, perseverance, and entrepreneurship.

Formal institutions are also treated differently in the transaction costs theory. They are constituted by the legal standards, the policy of the country, the adopted financial and tax system, and administrative procedures. The functions of these institutions are generally performed by certain organizations. Currently, the imperfection of the bureaucratic system is the biggest barrier in the development of companies, at the same time heightening their transaction costs. The introduction of comprehensive solutions to facilitate economic activity could improve managing them (Chotkowski 2010, pp. 107-108).

Apart from formal and informal institutions the transaction costs theory also covers civil society institutions and market infrastructure. It refers to the social capital and activity of citizens as well as market intermediaries whose aim is to provide the object of sale to the customer with the help of promotional, marketing, transport, information tools and many others. Without effective cooperation between institutions implementing these steps it is difficult to imagine the realization of market transactions (Kowalska 2005, p. 56).

\section{The concept and division of transaction costs}

Creating, maintaining and enforcing institutions with contracts as a form of cooperation are accompanied by transaction costs. So far a universal and comprehensive definition of the term has not been developed. For the purposes of the research subsequent interpretations of this term are made, which is often regarded as an area of weakness in the methodological area of a neo-institutional economy (Hardt 2006, pp. 1-23).

Initially, the transaction costs related mainly to the burden connected to agency in transactions. In the 1960s the concept of transaction was expanded due to the costs associated 
with searching for and obtaining market information and ultimately from the 1970s they have also covered the contracting, contract supervision and functioning of market institutions (Klaes 2001, p. 179). Some theorists believe that they are separable from the cost of production, while others point out that transaction costs should be considered as a component of the function of production and distribution costs (Gorynia 2007, p. 174).

According to Coase, an enterprise and the market do not work next to each other, but they are an alternative way to allocate different resources. In turn, transaction costs constitute the factor determining the size, type and structure of the created enterprise. Initially, the transaction costs were defined as the costs of using the price mechanism. Transaction costs in the area of microeconomics concern the separation of the production costs from the total value of operating costs. On the other hand, in the area of macroeconomics, transaction costs are heterogeneous and include the functioning of the institutional environment of the state regulating all planes of social life.

Despite the multiplicity of definitions being used, economists agree that transaction costs are always related to the conclusion of transactions, transfer of ownership and institutional system (Zbroińska 2013, p. 165). The common denominator in the definition of transaction costs is their non-productive origin and the institutional formation place.

Specific features of the transaction costs include frequent omitting and ignorance of their existence, failure to account for them economically, difficulty in quantification, treating them as a side effect of the transactions and the transfer of property rights. Transaction costs as a category are not recognized in accounting units due to methodological reasons, despite the impact on the results of operations. These costs are generated due to information asymmetry, inducing the parties into negotiation, and because of the high risk associated with them, also to insuring the contracts under which they arise. Transaction costs also arise in situations where the resources are used for the creation, maintenance and running of the institution as well as its usage and changes (Ząbkowicz 2003, p. 811).

Overall, the transaction costs can be divided into three types: market, intercompany and public costs. Market transaction costs are primarily the costs of searching and collecting information, conducting negotiations and decision-making concerning the conclusion of the agreement, monitoring the agreed deadlines, quantity and quality of the product, as well as the possible costs of enforcement of the rights and provisions of the contract. The intercompany transaction costs include, in turn, partly fixed costs and variable costs related to the functioning of the company. On the other hand, the public transaction costs are associated with organizing, maintaining and upgrading formal and informal public order and the costs of the society's functioning (Małysz 2003, pp. 315-340).

A similar classification was proposed by Ząbkowicz. These are the association of transaction costs with institutions with different operating range results in the diversity of these costs, which constituted the basis for their classification according to the type of the contracting parties' cooperation. Following this criterion market (tender), executive (management) and public (rationalizing) transaction costs were distinguished (Ząbkowicz 2003, p. 811). 
Among transaction costs, which, although difficult to quantify, one can distinguish several types of them, including (Kowalska 2005, p. 56):

- the costs of searching for information (on prices, contract partners, exchange sites, all aspects of carrying out the transaction, including, in particular, the quality of goods and services as well as the available factors of production and the potential behaviour of contract partners within the existing institutional structure),

- costs of the negotiations, which would disclose the real position of the contractual partners, assuming that prices are endogenous variable, depending on the outcome of negotiations,

- cost of formulation, recording (often with the use of costly legal opinions) and credibility (e.g. notaries) of the contract,

- costs of activities protecting from risk (security of the agreement),

- the costs of monitoring the behaviour of contracting partners and the degree of implementation of the contract,

- costs of implementation and enforcing the implementation of the contract's provisions,

- the costs of resolving disputes by consensus,

- costs of judicial enforcement of a contract or internalisation of costs in case of impossibility of the fulfilment of contractual obligations by the parties (case in which the costs of judicial enforcement exceed the value of the contract),

- costs of negotiating contracts,

- the costs of securing and protection of property rights against unauthorized persons.

Stankiewicz provides another division of costs. According to him, one should distinguish the following types of transaction costs (Stankiewicz 2007, p. 151):

- costs of the search for alternatives,

- costs of settlements,

- costs of concluding contracts,

- costs required procedures,

- costs of specification and protection of property rights,

- costs of opportunistic behaviour.

The lack of proper information while concluding the contract is a source of uncertainty related to the implementation of the contract, and thus it can generate costs which are unpredictable. The rarity of information means that obtaining it or its disclosure must cost, therefore all economic processes associated with the acquisition, processing information or are associated with the persistent shortage of information, generate a variety of transaction costs (Kowalska 2005, p. 56). 


\section{Management of transaction costs as a realization of the theory of transaction costs}

The conclusion of each contract is aimed at reducing transaction costs. The principle of this criterion is based on a comparison of the two options of solutions with similar costs related to the production and the final result, and one selects the option, in which the transaction costs turn out to be smaller. While making the choice one must be guided by the assets' specificity, frequency and uncertainty affecting the degree of detail as regards a particular contract. The decision simultaneously influences the level of transaction costs both in ex ante conceptualization and the ex post one described by Williamson (1998, p. 65). In addition, he presented the fundamental division between the two areas of research in the field of transaction costs - these are: the field of management, which defines the domain of the application of that theory and the area of measurement in which the empirical testing of theoretical concepts takes place.

The transactions referred to in theory are carried out under conditions of uncertainty associated with the risk. The greater the degree of specificity of assets, the greater the risk and the pursuit of belaying by the owner as early as at the stage of concluding the contract. One should also take into account that such agreements are accompanied by uncertainty as regards the loyalty of business partners, determined as behavioural uncertainty. Furthermore, the size of transaction costs is also affected by an increase in the frequency of conducting transactions, which reduces them. To identify the possibilities of reducing transaction costs, the table below lists the institutions and elements which may have influence.

\section{Table 1}

Differences in the amount of transaction costs

\begin{tabular}{ll}
\hline Lower transaction costs & Higher transaction costs \\
\hline Goods and services to be exchanged, standard & Goods and services to be exchanged, special kind \\
Clearly defined rights of the parties & Unclear rights of the parties \\
A small number of the contracting parties & Many contracting parties \\
Friendly relations between the parties & Unfriendly relations between the parties \\
The contractual parties know each other & The contractual parties don't know each other \\
$\begin{array}{l}\text { The mutual services of the parties are implemented } \\
\text { simultaneously }\end{array}$ & $\begin{array}{c}\text { Mutual services of parties to the agreement are not im- } \\
\text { plemented at the same time (exchange is postponed }\end{array}$ \\
$\begin{array}{l}\text { The exchange is unconditional } \\
\text { in time) }\end{array}$ \\
$\begin{array}{c}\text { The exchange is dependent on additional conditions } \\
\text { of the agreement } \\
\text { oudicial execution of contractual rights is cheap } \\
\text { and easy to implement }\end{array}$ \\
$\begin{array}{l}\text { The high costs of monitoring the implementation } \\
\text { of the agreement }\end{array}$ \\
\hline
\end{tabular}

Source: author's own work based Kowalska (2005), Stankiewicz (2007). 
Progress in the area of communication technology, easier access to information using electronic technology; significantly affect the reduction in market transaction costs. However, mass character and the anonymity of market transactions, on the other hand, generate a demand for advisory services, financial, market research, insurance, or the need for information management, and many other essential factors affecting the success of the transaction. In the end, it all contributes to a sharp increase in transaction costs in the economy scale as a whole (Zbroińska 2013, p. 168).

\section{Temporary work in the outline of the theory of transaction costs}

Temporary work involves an independent enterprise employing a jobholder and transferring him or her with the consent of that individual to a third party in order to provide temporary or permanent work. Hiring out employees is a system in which there are three parties involved:

- a lender offering the temporary contribution of their employees,

- entity declaring the demand for labour,

- employees performing the required work at the headquarters of the lending party.

Discussed relationship, which is very interesting and unusual, is shown in Figure 1. The employee is linked due to the contract of employment with a temporary work agency, but in fact performs services for third parties. Between employees who are hired out and the enterprise - user no contractual relationship occurs in the course of performing work. Outsourced staff are drawn into the organizational structure of the company declaring the demand for labour, they performs the stipulated tasks, while being obliged to carry out the orders of the lender.

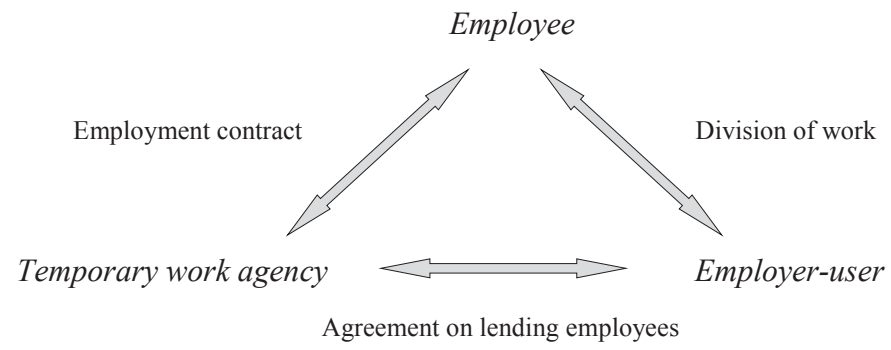

Figure 1. Entities involved in temporary work

Source: author's own work based on Storrie (2002).

It seems that it is worth looking at temporary work from the perspective of one of the three main components of the new institutional economics, namely - from the point of view of the transaction costs theory. As O. Williamson noted: "Each problem which can 
be directly or indirectly expressed as a contracting problem, should be rather discussed in terms of reducing the transaction costs" (Williamson 1998, p. 54). Developing this idea, one could put forward a thesis that the expansion of temporary work is conditioned - at least partly - by an attempt to save on transaction costs by entities running a business activity. Therefore, it is appropriate to ask the question: what kinds of transaction costs are associated with the conclusion of employment contracts, and which of them can be reduced due to temporary work? According to one of the divisions present in professional literature, one can distinguish the following types of transaction costs: market, intercompany and public costs. Costs incurred prior to the conclusion of the employment contract are included into the category of market transaction costs, which were incurred on the labour market. Examples of intercompany costs include the implementation of employment contracts between the company and the persons employed by the company, the cost of measuring the efficiency of the employees, and the costs of information processing. Another division of transaction costs concerns the distinction between ex ante and ex post costs. The ex ante costs are costs arising during the preparation and negotiation of contracts. They change depending on the type of goods produced and services (Małysz 2003, p. 323). According to Williamson, ex post costs include the costs of creating the management structure and operating it, the costs of monitoring, dispute resolution and other.

What benefits can a company obtain thanks to using the services of a temporary work agency?

The lack of perfect market information hinders the parties to conclude a contract of employment. An agency reduces the costs of searching, which would be incurred by an enterprise wishing to find a certain number of employees with the right qualifications. Saving time also has a considerable importance - one can get the required personnel generally almost immediately. An agency reduces also the aforementioned costs for an employee by releasing him or her from the effort of finding employment. Of course, the employee could look for a job vacancy himself or herself and conclude consecutively fixed-term contracts with different employers. The agency takes over these responsibilities. It collects information on vacancies from the market and associates labour supply with demand (matching), which reduces the risk of the employee being without a job for a long time. Moreover, the agency committing in the agreement to provide staff with specific qualifications, in some way vouches for employees and their skills, and thus it is easier for them to get a job. Intermediation in the labour market is undoubtedly a step towards the economization of information. An additional link in a data channel poses the threat of distortion regarding the provided information, that is why it is important to determine precisely between the company-user and the temporary work agency which employees the company needs. The enterprise, in turn, saves on the cost of checking the application documents, references, negotiation and the preparation of contracts. Instead of conducting negotiations with every candidate for a job it only concludes one agreement - with a temporary work agency. An agency therefore 
minimizes the number of transactions, especially in the case of employing more workers directly. These savings include savings on ex ante transaction costs, that is paving the way for an agreement and those related to its conclusion (Table 2).

\section{Table 2}

Transaction costs ex post, ex ante

\begin{tabular}{|c|c|c|}
\hline Ex ante costs & Problem & Solution to problem \\
\hline Search costs & No contact between seller and buyer & Advertising, mediation \\
\hline Costs of specifying & Undefined features of the exchange & $\begin{array}{l}\text { Communication as to the characteristics, } \\
\text { the participation of experts }\end{array}$ \\
\hline $\begin{array}{l}\text { The cost of collecting } \\
\text { information }\end{array}$ & Non-transparent markets & Price comparisons inefficiency \\
\hline $\begin{array}{l}\text { The cost of collecting } \\
\text { negotiations }\end{array}$ & $\begin{array}{l}\text { No agreement on the prices and } \\
\text { conditions }\end{array}$ & $\begin{array}{l}\text { The negotiations, contract development, } \\
\text { signing a contract }\end{array}$ \\
\hline Management costs & Unclear division of tasks & Prioritizing organizations \\
\hline Ex post costs & Problem & Solution to problem \\
\hline Supervision costs & $\begin{array}{l}\text { Uncertainty as to fulfil } \\
\text { obligations }\end{array}$ & $\begin{array}{l}\text { Control, concessions to date and payment, } \\
\text { quality measurement }\end{array}$ \\
\hline Realization costs & Unrealized ownership titles & $\begin{array}{l}\text { The participation of third parties (courts, } \\
\text { mediation) }\end{array}$ \\
\hline
\end{tabular}

Source: author's own work based on Małysz (2003).

What are the ex post costs, that is, the implementation and monitoring of the agreement? Temporary work (as well as fixed-term contracts) has a major advantage compared to permanent contracts as the company does not bear the costs of its termination. Moreover, it also does not bear the costs associated with training, apprenticeship, the risk of rotation and motivating employees. The company declaring the demand for temporary workers knows that if they do not meet its requirements or they are ill, it may request other workers. The company is some way buys the resource of work of a certain "quality", and with a guarantee of replacement. Individuals who are working and based on this form of employment tend to be seen as a multi-establishment reserve personnel, one can reach them as needed. Of course, the company has to pay the agency for maintaining the readiness. However, it is a cheaper alternative than the self-continuous maintenance of such workers within the enterprise. In addition, the employment of temporary workers does not require administrative work from the HR and accounting department which accompanies the autonomous employment by the company. Among other reasons why companies resort to temporary workers one should indicate the desire to achieve measurable savings on labour costs. A significant burden with these costs constitute a rule in many countries and it is not surprising that employers are looking for some ways to reduce it. Although companies do not always have a decisive impact on the level of direct wages, one method of reducing non-wage elements of remuneration is the use of atypical forms of employment. In the case of temporary work a company using hired out staff, not acting as an employer formally, omits non-wage labour costs, such 
as holiday pay, additional paid holidays, sick leave, additional bonuses fixed by a tariff and social security contributions. Besides, the salaries of such employees are in fact lower than the salaries of permanent employees. Above all, however, temporary employees allow the company to cushion the unexpected fluctuations in the demand for labour. Apart from the advantages of this type of agreement for employers one should also indicate some of their shortcomings. Research shows that these employees are on average less productive, less motivated, and one has to incur greater expenditures connected to their implementation to the work and control.

\section{Conclusions}

The creation of the concept of new institutional economics was caused by focusing on the legal-institutional environment and its role regarding the market mechanism (characteristic of classical economics) in shaping many economic processes. Institutions, understood in the theory of transaction look differently than how this word is actually understood, characterized by different elements of the environment and rules, as well as the personality traits of people taking different decisions on the market; they affect the efficiency of the economy and the pace of change or adaptation. Markets also constitute an institution and should evolve in the direction of an efficient market. After all, the greatest institution is the state. Although the concept of transaction costs uses the achievements and theoretical principles of neoclassical economics, it still contains elements of new institutional economics, which it incorporated. According to this theory, the institutions as rules of behaviour of all market players as well as structures of managing them undergo the modifications which lead to the lower costs of the whole economic system. The reduction of transaction costs constitutes one dimension of increase of effectiveness connected to operating on the market and it is a positive phenomenon (Chotkowski 2010, pp. 107-108).

The weaknesses of the neo-institutional approach include first of all the problem of the operationalization of transaction costs, which are most often immeasurable. Their identification, however, is simplified by a contractual approach. The enterprise in this context is a party of the contract or agreement both external in relations with other market participants and the state as well as a party in transactions with staff (Zbroińska 2013, p. 172).

Although the primary part of the elements regarding the institutional system, e.g. legal regulations, economic and administrative system, including the tax system, is shaped in the framework of the decisions of state policy, a large part of the decisions affecting the reduction of transaction costs depends on the enterprises themselves. The main problem of the implementation of guidelines of the new institutional economics to business practice is to find the right balance in the contracting process concerning transactions between freemarket mechanisms and hierarchical management structures. These relationships depend on four key dimensions of a transaction: the specificity of the assets at the disposal of the market participants, uncertainty, complexity and frequency of the transactions. Transaction 
cost economics emphasizes that, especially in conditions of high asset specificity, the uncertainty and frequency of transactions, the costs of internal coordination can be lower than the free-market transaction costs.

To sum up the above considerations, one can conclude that temporary work agencies allow companies to achieve savings in transaction costs related to the hiring of personnel. One has to realize, however, that conducting an accurate analysis and empirical account of these costs is difficult. This is a basic limitation of the transaction costs theory as a research tool. Another disadvantage is its excessive descriptive character and little formalization. The transaction costs theory explains the blurring boundaries of the enterprise and the flattening of the structures within concepts such as outsourcing, downsizing, and lean management. It also enables the explaining of the expansion of organizational innovation and new forms of employment.

\section{References}

Chotkowski J. (2010). Market institutions and transaction costs - key notions in new institutional economy. Roczniki Nauk Rolniczych, 97 (2), 107-108.

Gorynia M. (2007). Studies on transformation and internatiolization of Polish economy. Warszawa: Difin.

Hardt Ł. (2006). Birth and evolution of the meaning of the transaction costs notion. Gospodarka Narodowa, 11-12, $1-23$.

Klaes M. (2001). Begriffsgeschichte: Between the Scylla of Conceptual and the Hybrids of Institutional History of Economics. Journal of the History of Economic Thought, 23 (2), 179.

Klaes M. (2000). The History of the Concept of Transaction Costs: Neglected Aspects. Journal of the History of Economic Thought, 22 (2), 192.

Klimczak B. (2005). Remarks on associations between the standard economy and new institutional economy. In: S. Rudolf (ed.), New institutional economy. Theoretical and practical aspects. Kielce: Publishing House of Higher Institute for Economics and Administration.

Kowalska K. (2005). Contractual and transaction costs in new institutional economy. Gospodarka Narodowa, 7-8.

Lichtarski J. (2007). Basics of knowledge on an enterprise. Wrocław: Publishing House of O. Lang Academy of Economics in Wrocław.

Małysz J. (2003). Institutions versus transaction costs in the light of neo-institutional economy. Ekonomista, 3, $315-340$.

Stankiewicz W. (2007). Institutional economy. Outline of the lecture. Warszawa: PWSBiA.

Storrie D. (2002). Temporary agency work in the European Union. Luxembourg: European Foundation for the Improvement of Living and Working Conditions.

Williamson O. (1998). Economic aspects of capitalism. Companies, markets, contractual reactions. Warszawa: Wydawnictwo Naukowe PWN.

Wrońska E.M. (2012). Transaction cost theory versus Professional groups. Annales Universitatis Mariae CurieSkłodowska Lublin - Polonia, 46 (1).

Ząbkowicz A. (2003). Modern institutional economy in the light of major economy trend. Ekonomista, 6, $795-823$.

Zbroińska B. (2013). The contribution of transaction costs economy and theory of contracts as regards the studies on management. Studies and Materials of Jan Kochanowski University in Kielce, 2, 164-169. 


\section{MOŻLIWOŚCI WYKORZYSTANIA TEORII KOSZTÓW TRANSAKCYJNYCH W ZARZĄDZANIU PRZEDSIĘBIORSTWEM}

Streszczenie: $\mathrm{Cel}$ - Teoria kosztów transakcyjnych jest jedną z trzech nowych - neoklasycznych - koncepcji przedsiębiorstwa, stojących w opozycji do teorii klasycznych, rozpatrujących przedsiębiorstwo jako „,zarną skrzynkę", tj. zamknięty organizm (black box), którego celem firmy jest efektywne przekształcanie nakładów w wyniki, a analiza efektywności była dokonywana przez pryzmat kosztów produkcji. Mechanizmy rynkowe regulują funkcjonowanie rynku, bowiem przedsiębiorstwa działają na rynku traktowanym jako sfera konfrontacji podaży z popytem (równowaga cenowa). Podejście neoklasyczne nie uwzględniało natomiast nacisku różnych instytucji regulujących warunki prowadzenia działalności gospodarczej. W teoriach neoinstytucjonalnych na plan pierwszy wysuwa się postrzeganie przedsiębiorstwa szerzej niż jako „,zarnej skrzynki" i przez pryzmat funkcji produkcji.

Celem artykułu jest przedstawienie dociekań naukowych w zakresie możliwości wykorzystania teorii kosztów transakcyjnych w zarządzaniu przedsiębiorstwem.

Metodologia badania - Na potrzeby niniejszej pracy zostały wykorzystane następujące metody badawcze: krytyczna analiza literatury, sondażu diagnostycznego (scenariuszowa) oraz metoda badań porównawczych (komparatystycznych). Wykorzystano również metodę syntezy, dedukcji i indukcji.

Wynik - W wyniku przeprowadzonych badań wykazano, iż porównanie kosztów transakcyjnych powinno decydować o koordynacji działalności przez firmę, a nie przez rynek - jeśli koszty transakcyjne są mniejsze wewnątrz firmy, to opłacalne jest zorganizowanie produkcji w firmie, jeśli są wyższe na rynku niż w firmie - nieopłacalne będzie produkowanie dóbr przez przedsiębiorstwo. W tym kontekście istotne jest uwzględnienie wewnętrznych rozwiązań w firmach - przy założeniu, że większość czynników produkcji wykorzystują właśnie przedsiębiorstwa, a wykorzystanie tych dóbr podlega decyzjom firm, a nie bezpośrednio działaniom sił rynkowych. Funkcjonowanie rynku zależy w znacznym stopniu nie od sił rynkowych, ale od tego w jaki sposób działają przedsiębiorstwa.

Oryginalność/wartość - Przeprowadzona analiza stwarza podwaliny do dyskusji na temat wdrożenia teorii kosztów transakcyjnych poprzez m.in. tworzenie grup zakupowych, w celu polepszenia pozycji negocjacyjnej z kontrahentami (zmniejszenie kosztów poszukiwania informacji) lub wykorzystania pracowników podmiotów trzecich (praca tymczasowa - zmniejszenie kosztów przygotowania produkcji).

Słowa kluczowe: zarządzanie kosztami, ekonomia kosztów transakcyjnych, asymetria informacji, ekonomia instytucjonalna, kontraktualna teoria przedsiębiorstwa

\section{Citation}

Suska J. (2016). Possible Applications of the Theory of Transaction Costs in Corporate Management. Finanse, Rynki Finansowe, Ubezpieczenia, 4 (82/1), 251-263. DOI: 10.18276/frfu.2016.4.82/1-21. 